GLOBAL JOURNAL OF EDUCATIONAL RESEARCH VOL 16, 2017: 29-35

COPYRIGHTC BACHUDO SCIENCE CO. LTD PRINTED IN NIGERIA. ISSN 1596-6224

\title{
TRAINING NEEDS OF SCHOOL INSPECTORS FOR QUALITY INSTRUCTION IN DELTA STATE PRIMARY SCHOOLS
}

\section{JUDE EKUEVUGBE OMORIGHO}

(Received 21, December 2015; Revision Accepted 5, February 2016)

\begin{abstract}
The need to meet up with the complexity of the education industry and the pressing need for quality education in Nigeria is an intricate task. This paper seeks to identify the basic training needs required by school inspectors and recommends how quality training for school inspectors can enhance Primary school effectiveness. The ex-post facto research design was adopted in the study and the population consisted of 565 School inspectors in the Delta State Central Senatorial District. The findings revealed that inspectors had strong desire to be trained in education law, school communication and school inspection. Recommendation among others in order to achieve the desired level of quality instruction and school effectiveness, the above major needs be incorporated in the training programmes for Primary School Inspectors.
\end{abstract}

KEYWORDS: Quality, instruction, training need, inspection.

\section{INTRODUCTION}

One of the most enduring legacies parents and the country can pass on to its youth is education. Primary education is regarded globally as the bedrock or foundation of all other higher levels of education. As a result, any mistake made at this level will have adverse effect on other higher levels of education and by implication the nation (Onyeukwu and Nwanoruo, 2006). From the foregoing therefore, it becomes imperative that primary education must be adequately positioned for effectiveness and efficiency. One of the ways of repositioning primary education is the resuscitation and equipping of the inspectorate division. (Nwaham, (2008); Okwilagwe (2007) stressed that in order to achieve efficiency in inspection and school effectiveness; there is need for proper monitoring of schools facilities and personnel (teachers). The sole responsibilities of enhancing these, lies with the headmasters and the school inspectors. In support of this view also, Nnabuo (1996) opined that the quality of instruction in a school depends on the extent to which the headmasters and inspectors are performing their supervisory functions in the primary schools. Hornby (2003) describe quality as standard of something when compared to other things. From the above, quality connotes a concept rooted in comparison. The concept of quality is an intrinsic part of education. Hence, instruction in school situation is a means of transmitting knowledge and things worthwhile to pupils by teachers (Nnabuo, 1996). In the same vein, Fagbamiye (1995) contended that if school inspections are to become tools for improvement of primary school processes for effective quality instruction, there should be a rethink of the way and manner their functions being carried out in accordance with the present educational trend. The present educational trend in this regard is effective communication and educational law. That is why Ahmed (1988) propounded that for inspectors' to perform optimally there should be improved managerial skills (effective training) to inculcate effective communication and education law. This will remove mediocrity from the Primary School

Jude Ekuevugbe Omorigho, Post Primary Education Board, Asaba, Delta State, Nigeria. 
inspectors for effective educational service delivery in the Primary School system. Training is therefore the assessment of the requirement of school inspectors. In the light of the above, training needs is concerned with the identification and acquisition of a body of knowledge and skills which can be applied to work of a particular type. The world is fast growing and inspectors need to be updated in line with Maslow's principle hypothesis that human beings have common group of needs which tend to be satisfied in a more or less hierarchical way of which self actualisation is the last stage. In this way, many inspectors and others in the educational sector depend on the acquisition of such basic skills. Inservice training enables the inspector to develop such supervisory skills such as education law and communication skill. Igwe (1992) posited that the whole concept of training of inspectors is to make them self reliant, productive, functional, competent and efficient in supervision in consonance with Okwilagwe (2007) who noted that training and retraining of inspectors can no longer be discountenanced when issues on quality instruction provision are needed.

It should be noted that education has created great awareness among people that many things which the headmasters, teachers and school inspectors took for granted in the past no longer hold today. People now challenge some of the actions of the school authorities by way of litigation in the law court. Inspectors and teachers are held responsible for any act of negligence resulting from failure to act reasonably in situations involving pupils in their care. By acting in accordance with the education law, school inspectors and teachers can save themselves and their employers from embarrassment and costly litigation in many ways in the discharge of their legitimate professional obligation (Nwadiani, 1998). In support of this statement, Maduagwu (1997) noted with concern that of all areas in education law perhaps the section dealing with pupils and punishment are more delicate. The understanding of this will enhance the confidence and competence of inspectors in embarking on effective supervision in the primary school level.

However, these education laws cannot be effectively implemented if there is no effective communication. One of the common causes of inefficiency in school inspection is poor communication. Peretomode (1995) defined communication as the process of transmitting and imparting information from a sender to receiver. The Federal Government of Nigeria (FRN, 2004) noted that communication is the process by which information is exchanged in order to initiate action. Since communication is the process of exchange of information, message, ideas, attitude, feelings and reactions, some educationists have developed a simple, universally satisfactory communication system such as communication by word, written, symbol or the use of electric devices (Nwaham, 2008). Effective communication training for school inspectors therefore is important for the improvement of instruction, learning and the curriculum (Nnabuo, 1996). In support of this view, Omachonu (2005) affirmed that through effective communication, an inspector can use language to move people to action by giving them a reason to act, presenting a clear plan of action and making it clear for them to comply. This corroborates the view of Holleman (2003), who argued that well developed curriculum, wellqualified staff and attractive benefit, could not produce the desired effect unless they are adequately communicated to both teachers and pupils by inspectors. The questions this paper seeks to ask are:

(i). Do primary school inspectors have training in effective communication?

(ii). Are they skilled in educational law? This is because where there is no law ignorant is promoted. Hence, this paper seeks to examine whether our primary school inspectors have these training.

\section{Statement of the Problem}

The quality of instruction in primary schools in Delta state have become an issue of great concern to government and stakeholders in education. In order to proffer solution to the situation, there may be need for training for school inspectors to enhance effective supervision of schools. Based on this, the study determines the major training needs of inspectors for effective supervision of primary schools in Delta state. Hence, the paper intends to investigate the training needs of school inspectors for effective supervision of primary schools for effective service delivery.

\section{Purpose of the study}

The main thrust of this study, is to investigate the major training needs required by school inspectors to enhance primary school 
supervision. Specifically, the purpose of the study is to determine whether:

(i). Primary school inspectors have training in effective communication.

(ii). They are skilled in educational law.

\section{RESEARCH QUESTIONS} the study.

The following research questions guided

(i) Is there any difference in the mean response between inspectors and headmasters?

on the need to train inspectors on school supervision?

(ii) Is there any difference in the mean response between inspectors and headmasters?

on the need to train inspectors on effective school communication?

(iii) Is there any difference in the mean response between inspectors and headmasters?

on the need to train inspectors on education law?

\section{Null Hypotheses}

The following null hypotheses were formulated and tested at 0.05 level of significant.

$\mathrm{Ho}_{1}$ : There is no significant difference in the mean response between inspectors and headmasters on the need to train inspectors on school supervision.
$\mathrm{Ho}_{2}$ : There is no significant difference in the mean response between inspectors and headmasters on the need to train inspectors on effective school communication.

$\mathrm{Ho}_{3}$ : There is no significant difference in the mean response between inspectors and headmasters on the need to train inspectors on education law.

\section{METHODS}

The researcher adopted the ex-postfacto research design. This is because the design was very appropriate where it was not possible for the researcher to directly manipulate the independent variables (training needs components) having cause-effect relationships on effective supervision of schools. Indeed the researcher only attempted to link some already existing effects (Training needs components) as causative agents.

\section{POPULATION OF THE STUDY}

The population of the study consisted of all public primary school inspectors in the eight Local Government Areas of Delta Central Senatorial District. It is comprised of 565 subjects made up of 148 inspectors and 417 headmasters as contained in table 1. The inspectors and headmasters perform supervisory functions.

Table 1: Population of the Study

\begin{tabular}{|l|l|l|l|l|}
\hline S/N & L.G.A & INSPECTORS & HEADMASTERS & TOTAL \\
\hline 1 & Ethiope-East & 14 & 64 & 78 \\
\hline 2 & Ethiope-West & 23 & 38 & 61 \\
\hline 3 & Okpe & 24 & 40 & 64 \\
\hline 4 & Sapele & 18 & 54 & 72 \\
\hline 5 & Udu & 10 & 34 & 44 \\
\hline 6 & Ughelli-North & 22 & 91 & 113 \\
\hline 7 & Ughelli-South & 15 & 67 & 82 \\
\hline 8 & Uvwie & 22 & 29 & 51 \\
\hline & Total & $\mathbf{1 4 8}$ & $\mathbf{4 1 7}$ & $\mathbf{5 6 5}$ \\
\hline
\end{tabular}

Sources: Statistics Division. SUBEB, Asaba (2008) 
The study focuses on inspectors and headmasters of public primary schools because various studies involving school inspection recognizes the latter as performing supervisory roles in schools. Their reasons were that, the headmasters know the school communities, the teachers, pupils better and possess adequate knowledge of the curriculum than anyone else hence supervisor is described as the most important responsibility of the headmaster (Adesina, 1981).

\section{Sample and Sampling Technique}

The sample of this study was 235 of the public primary school inspectors in the Delta Central Senatorial District. Yaro Yamene's formula was used.

Table 2: Sample size by local government areas of inspectors and headmasters

\begin{tabular}{|l|l|l|l|l|}
\hline S/N & LGA & INSPECTORS & HEADMASTERS & TOTAL \\
\hline 1 & Ethiope-East & 06 & 27 & 33 \\
\hline 2 & Ethiope-West & 10 & 15 & 25 \\
\hline 3 & Okpe & 11 & 17 & 28 \\
\hline 4 & Sapele & 07 & 22 & 29 \\
\hline 5 & Udu & 04 & 14 & 18 \\
\hline 6 & Ughelli-North & 09 & 38 & 47 \\
\hline 7 & Ughelli-South & 06 & 28 & 34 \\
\hline 8 & Uvwie & 09 & 12 & 21 \\
\hline \multicolumn{2}{|c|}{ Total } & $\mathbf{6 2}$ & $\mathbf{1 7 3}$ & $\mathbf{2 3 5}$ \\
\hline
\end{tabular}

This sampling procedure was adopted because according to Peretomode and Ibeh (1992), the proportionate stratified random sampling technique gives a more representative sample since it ensures proportional representation of all sub-groups of the population. Proportionate stratified random sampling guarantees that minority constituents of the population are represented in the sample and the associated sampling error is reduced, compared with the simple random sampling (Nworgu, 2006).

Research Question 1: Is there any difference in the mean response between inspectors and headmasters on the need to train inspectors on school supervision?

The mean and standard deviation was used to answer the research questions as presented in table

Table 3: The mean rating of the respondents on the needs to train inspectors on effective school supervision

\begin{tabular}{|l|l|l|l|}
\hline Respondents & $\mathbf{X}$ & SD & Decision \\
\hline Inspectors & 3.12 & 0.25 & Important \\
\hline Headmasters & 2.96 & 0.11 & \\
\hline
\end{tabular}

Table 3, shows that the individual means of the items are each higher than the acceptable mean of 2.50. This means that if each of the strategy is adopted will improve school supervision.
Hypothesis 1: There is no significant difference between the mean response of inspectors and headmasters on the need to train inspectors on school supervision 
Table 4: Z-test analysis on the mean response between inspectors and headmasters on the need to train inspectors on school supervision

\begin{tabular}{|l|l|l|l|l|l|l|l|l|l|}
\hline Respondents & $\overline{\mathbf{N}}$ & $\mathbf{X}$ & SD & $\mathbf{d f}$ & $\begin{array}{l}\text { Std } \\
\text { error }\end{array}$ & $\begin{array}{l}\text { Z- } \\
\text { calc }\end{array}$ & $\begin{array}{l}\text { Z- } \\
\text { crit. }\end{array}$ & Prob & Decision \\
\hline Inspectors & 62 & 3.12 & 0.25 & 233 & 0.03 & 4.82 & 1.96 & 0.05 & $\mathbf{S}$ \\
\hline Headmasters & 173 & 2.96 & 0.11 & & &
\end{tabular}

Table 4 showed that the calculated $Z$ (4.82) > critical Z (1.96), at 0.05 level of significance. Therefore, the null hypothesis which stated that there is no significant difference between the mean response of inspectors and headmasters on the need to train inspectors on school supervision was not accepted.
Research question 2: Is there any difference between the mean response of inspectors and headmasters on the need to train inspectors on school communication?

Table 5: 'The mean rating of the respondents on the needs to train inspectors on school communication

\begin{tabular}{|l|l|l|l|}
\hline Respondents & $\mathbf{X}$ & SD & Decision \\
\hline Inspectors & 3.51 & 0.24 & Important \\
\hline Headmasters & 3.13 & 0.10 & \\
\hline
\end{tabular}

Table 5 showed grand mean score of 3.51 and 3.13 for the respondents. This depict that the respondents indicated strong desire to be trained in school communication for achieving quality supervision of school having scored the mean higher than the acceptable mean of 2.50 .
Hypothesis 2: There is no significant difference between the mean response of inspectors and headmasters on the need to train inspectors on schools communications.

Table 6: Z-test analysis on the mean response of inspectors and headmasters on the need to train inspectors on school communication

\begin{tabular}{|l|l|c|l|l|l|l|l|l|l|}
\hline Respondents & $\overline{\mathbf{N}}$ & $\mathbf{X}$ & $\mathbf{S D}$ & $\mathbf{d f}$ & $\begin{array}{l}\text { Std } \\
\text { error }\end{array}$ & z-cal. & z-crit. & Prob & Decision \\
\hline Inspectors & 62 & 3.31 & 0.17 & & & & & & \\
\cline { 1 - 2 } Headmasters & 173 & 3.13 & 0.08 & 233 & 0.02 & 5.63 & 1.96 & 0.05 & $\mathbf{S}$ \\
\hline
\end{tabular}

Table 6 showed that $Z$ - value $(5.63)>$ the critical $Z( \pm 1.96)$, at 0.05 level of significance. Therefore, the null hypothesis, which stated that there is no significant difference between the mean response of inspectors and headmasters on the need to train inspectors on school communication is not accepted
Research Question 3: Is there a difference in the mean response between inspectors and headmasters on the need to train inspectors on education law?

To answer research question 2, the mean and standard deviation was carried out and the data generated was presented in table 4.5. 
Table 7: The mean rating of respondent on the need to train inspectors on education law

\begin{tabular}{|l|l|l|l|}
\hline Respondents & X & SD & Decision \\
\hline Inspectors & 3.24 & 0.22 & Important \\
\hline Headmasters & 2.98 & 0.09 & \\
\hline
\end{tabular}

From table 7 above, respondents agree that there is a need to train school inspectors on education law. This is shown by a grand mean of 3.24 and 2.98 scored by the respondents. The two grand means are above the mean of 2.50 , which is the acceptance level.
Hypothesis 3: There is no significance difference between the mean response of inspectors and headmasters on the need to train inspectors on education laws.

Table 8: Z-test analysis on the mean response of inspectors and headmasters on the need to train inspectors on education law.

\begin{tabular}{|l|l|l|l|l|l|l|l|l|l|}
\hline Respondents & $\mathbf{N}$ & $\mathbf{X}$ & SD & Df & $\begin{array}{l}\text { Std } \\
\text { error }\end{array}$ & $\begin{array}{l}\text { Z- } \\
\text { calc. }\end{array}$ & $\begin{array}{l}\text { Z- } \\
\text { crit. }\end{array}$ & Prob & Decision \\
\hline Inspectors & 62 & 3.24 & 0.22 & 233 & 0.03 & 8.97 & 1.96 & 0.05 & $\mathbf{S}$ \\
\hline Headmasters & 173 & 2.98 & 0.09 & & & & \\
\hline
\end{tabular}

Table 8 showed that the obtain $Z$ value was 8.97.This was found to be greater than the $Z$ critical value of \pm 1.96 at 0.05 level of significance. This shows that there was significant difference in the mean response of inspectors and headmasters on the need to train inspectors on education law. The null hypothesis which stated that there is no significant difference between the mean response of inspectors and headmasters on the need to train inspectors on education law was not accepted.

\section{FINDINGS}

The need to train school inspectors in school supervision: There was significance difference in the mean response of inspectors and headmasters on the need to train inspectors on school supervision, in agreement with Weis and Pasley (2003) who noted that inspectors need a vision of effective supervision to guide the design and implementation of their instructions. This implies that inspectors should be trained in the practical details of supervision to enable them offer professional advice and guidance to teachers.

The need to train school inspectors in education law: The findings from the analysis of data showed a significant difference in the mean response of school inspectors and headmasters on the need to train inspectors on education law. This is in corroboration with Maduagwu (1997) findings, that education law is of vital importance to school inspectors in consonance with Nwaham (2008) who stated that school organization is a very complex one, that inspectors are involve directly or indirectly in the organization and administration of schools. As a result there is, need to equip inspectors with the knowledge of education law for effective maintenance of law, order and discipline in schools.

The need to train inspectors in school communication: The findings from the analysis of data in hypothesis four show that there was significant difference in the mean response of inspectors and headmasters on the need to train inspectors in school communication. Omachonu (2005) affirmed that through effective school communication, the inspector can use language to move teachers to action by presenting a plan of action, and making educational policies and programmes lucid for teachers to comply with. The findings is in agreement with Hollenman (2003), that well developed curriculum, qualified staff and attractive benefits cannot produce the desired effect in schools' unless clear educational policies and programmes are adequately 
communicated to teachers and pupils by schools inspectors'.

\section{CONCLUSION}

Based on the findings of this study, it shows that Inspectors need adequate training in education law and communication, to be effective in primary school supervision.

\section{RECOMMENDATIONS}

The following recommendations were made in order to improve supervision for primary school effectiveness in Delta state.

Training and re-training of school inspectors: Education is dynamic; as new ideas in science and advancing technology, globalization have overtaken our societies. Therefore, training is recommended for all categories of inspectors in education law and modern communication.

Provision of in-service training: The government should provide opportunities for inservice training programmes on effective school supervision for inspectors using education law and school communication skills especially in primary schools.

Establishing an effective supervising policy: The government should ensure that schools inspectors' trained in the knowledge of education law and school communication should be allowed to do quality instruction passage to primary schools teachers during inspection.

\section{REFERENCES}

Ahmed, K., 1988. Improving the quality of technical and vocational education in Nigeria.

Fagbamiye, E. O., 1995. Providing adequate staff for the primary school system. A paper presented at the national conference on relaxing manpower constraints to Nigeria's economic development. Akoka: University of Lagos.

Federal Republic of Nigeria, (FRN)., 2004. National policy on education ( $4^{\text {th }}$ edition). Lagos: NERDC
Holleman, K. Z., 2003. The role of social and behavioural science in policy making. Journal of social issues, (32): 4.

Hornby, A. S., 2003. Oxford advanced learner's dictionary of current English. London: Oxford University Press.

Maduagwu, S. N., 1997. Education law: Legal aspects of school administration, principle and cases. Port-Harcourt: Emhal Printing/ Publishing Co.

Nnabuo, P. O. M., 1996. Supervision and inspection: A humanistic approach. PortHarcourt, Nigeria: Bengray Publishing Co.

Nwadiani, M., 1998. Educational management for sub-saharan African. Benin City: Monose Amalgamates.

Nwaham, C. O., 2008. School administration and supervision of instruction in Nigeria. Agbor: Krisbec Publication.

Okwiligwe, E. A., $9^{\text {th }}$ February, 2007. Evaluating private and public school dichotomy. Nigerian Tribune, 35

Omachonu, G. S., 2005. Cultural renaissance language empowerment and national development. A paper presented at the first international conference organized by the faculty of arts and humanities. Anyigba: Kogi State University.

Onyenkwu, F and Nwanorou, C., 2006. Strategies for repositioning primary education in Nigeria for effectiveness and efficiency. Journal of Research Development, 7(6),

Peretomode, V. F., 1995. Introduction to educational administration, planning and supervision. Lagos: Joja Educational Research and Publisher Ltd. 
